\title{
СОЦИАЛЬНАЯ СТРУКТУРА,
}

\section{СОЦИАЛЬНЫЕ ИНСТИТУТЫ И ПРОЦЕССЫ}

УДК 07.00 .03

$10.17213 / 2075-2067-2019-4-135-144$

\section{МИРОТВОРЧЕСТВО ЯСИРА АРАФАТА \\ КАК ПОПЫТКА ФРОНТИРНОГО ИЗМЕНЕНИЯ ЖИЗНЕННОГО ПРОСТРАНСТВА ПАЛЕСТИНЫ И ИЗРАИЛЯ}

(C) 2019 г. В. С. Прядеин*, С. М. Абрамов**, С. А. Акулов**, Н. А. Паикевич***

*Уральский федеральный университет (филиал), г. Верхняя Салда

**Уральский государственный горный университет, г. Екатеринбург ***Уральский государственный университет путей сообщения (филиал), 2. Нижний Тагил

В статье рассматривается один из многогранных и противоречивых феноменов Я. Арафата - миротворчество. Одновременно в работе называются причины, обусловившие переход лидера палестинского народа к миротворческой политике. Миротворчество рассматривается как скрытая форма, предполагающая неизбежное фронтирное изменение жизненного пространства между Палестиной и Израилем. Подчеркивается, что историческая травма палестинского народа связана с негативным опытом построения государственности. Утверждается, что манипуляция международным общественным мнением (непросвещенными слушателями) в пользу палестинских арабов, шантаж образом непостижсимого страдания и, как следствие, возможным негативным сценарием конфликта содействовали искажению реальности и транспарентности палестино-израильских отношений.

Ключевые слова: Ближний Восток; палестино-израильский конфликт; Ясир Арафат; миротворчество; Организаџия Объединенных Наџий; религиозно-националистический терроризм.

The article discusses one of the most-sided and contradictory phenomena of Y. Arafat peacekeeping. At the same time, the reasons for the transition of the leader of the Palestinian people to a peacekeeping policy are mentioned in the work. Peacekeeping is seen as a hidden form, suggesting the inevitable frontier change in the living space between Palestine and Israel. It is emphasized that the historical injury of the Palestinian people is associated with negative experience of building statehood. It is argued that the manipulation of international public opinion (unenlightened listeners) in favor of the Palestinian Arabs, blackmailing the way of inconceivable suffering and, consequently, a possible negative conflict scenario, contributed to the distortion of reality and transparency of Palestinian-Israeli relations.

Key words: Middle East; Palestinian-Israeli conflict; Yasser Arafat; peacekeeping; United Nations; religious-nationalist terrorism. 
О нем написано множество исследований: его жизнь и политическая деятельность подробно проанализированы последователями и критиками. Наиболее значимыми являются труды А. М. Васильева, Е. М. Примакова, Г.И. Мирского, Г. Концельмана, М. Штереншиса, А.Д. Эпштейна. Не имеет смысла повторять сказанное. Интереснее раскрыть и осветить феномен миротворчества Я. Арафата, который требует критического подхода и интерес к которому растет. Это не удивительно, так как палестино-израильский конфликт никуда не ушел, урегулирования конфликта не произошло и, по всей видимости, не произойдет. По мере обострения палестино-израильского конфликта и нарастания все менее управляемого хаоса будет возрастать интерес к переосмыслению политической деятельности Арафата, в том числе и в западной интеллектуальной традиции, где он традиционно воспринимается как часть национально-освободительной борьбы палестинского сообщества, чьи «...беды всегда на совести других» [8].

Писать историю палестино-израильского конфликта не означает выпрямлять его противоречия с учетом их исторического переплетения, которыми перенасыщено прошлое и настоящее, преодоление которых только на первый взгляд логично связано с «миротворческой» деятельностью Я. Арафата. Тем не менее, феномен миротворчества Арафата составляет важную и неотъемлемую часть палестино-израильского конфликта с его многообразием разнородных мифов и истин, которые придают смысл прошлому и проблемам его настоящего. Болезненный опыт прошлого из истории палестино-израильского конфликта превратился в груз неприятных воспоминаний и переживаний в настоящем. Как следствие, в палестинском обществе происходит неизбежное - прошлое становится релевантным для настоящего. Тем не менее, историческая «травма» палестинского народа, связанная с негативным опытом построения палестинского государства, образование которого не было предусмотрено резолюцией ООН от 29 ноября 1947 года, упорно возвращает его к прошлому. Именно тогда, в прошлом, «арабы отказались признать решение $\mathrm{OOH}$, а прагматики-сионисты его приняли, включая и пункт о передаче Иерусалима под международный контроль», - справедливо указывает Карен Армстронг [1]. Отметим, что «все предложения по разделу Эрец-Исраэль, включая резолюцию ООН 1947 г., говорили о еврейском и арабском государствах, ни одно из которых не называлось «палестинским» [5].

Надо помнить, что выбора, альтернативы у евреев не было. Даниэль Гордис справедливо говорит: «После всего, что евреи пережили, они не могли терять времени. И у них не было права на неудачу» [6]. В итоге в данной ситуации и период времени евреи были готовы к переменам больше, чем арабы, что относится больше к конъюнктурному аспекту (если принимать во внимание отдельные обстоятельства и условия), чем цивилизационному уровню развития. Напротив, арабское государство в Палестине так и не было образовано. Та часть Палестины, которую в ходе войны за независимость 1948-1949 гг. израильтяне не успели занять, была присоединена к граничившей с ней Трансиордании, впоследствии преобразованной в Королевство Иордания.

С нашей точки зрения, в 1947-1948 гг. Израиль не пытался установить контроль над арабами Палестины и, тем более, сдерживать процесс строительства Палестинского государства. Отметим, что арабы Палестины не были готовы к его образованию по ряду причин.

1. Внешние:

a) внешнее давление - арабы не хотели «Палестины», «они не знали этого народа» (не случайно арабские страны не предоставляют палестинским беженцами гражданство);

б) Советский Союз заигрывал с палестинскими арабами - это миф (причем израильский), наоборот, И.В. Сталин рассчитывал на единую Палестину в противовес арабскому традиционализму.

2. Внутренние:

a) пестрота интересов и культур разнородного состава «палестинского народа»;

б) уровень развития «Палестины» — аграрное и ремесленное производство;

в) отсутствие ментального единства, даже на религиозном уровне;

г) клановый характер организации общежития, кланы не могут организовать государство. 
Как следствие, арабы Палестины оказались в сфере непреодолимых ограничений и возможностей строительства суверенного государства. К тому же была потеряна обратимость процесса и «точка возврата» пройдена. Запоздалый разворот арабов, которые уже имели свои государства, в сторону идеи поддержки создания палестинского государства был обусловлен их поражением и новой конфигурацией ближневосточных отношений, а также втягиванием $\mathrm{OOH}$ в решение ближневосточных проблем, что придавало этому процессу международную легитимность. Другой фактор был связан с тем, что «палестинский народ», который конструировался искусственно, рассматривался арабскими государствами, скорее всего, в качестве противовеса Израилю.

Инверсионные возвращения коллективной памяти к прошлому мешают способности палестинских арабов жить в настоящем, ибо травма затронула их важнейший архетип — землю, территорию. Одержимость прошлым становится патологической и мучительной, поэтому есть опасность, что прошлое палестино-израильского конфликта станет его будущим. При этом она не может быть обратимой. Кроме того, демонизация Израиля в массовом сознании и исторической памяти палестинских арабов не позволяет последним осознать и осмыслить глубинные корни и причины палестино-израильского конфликта, основная проблема которого заключается в ограниченном спросе на его урегулирование. Очевидно, что ключевым образом коллективной памяти палестинских арабов является «образ врага», Израиль по-прежнему рассматривается как носитель угрозы существованию палестинского общества. С позиции аналитической психологии К. Г. Юнга, данный образ связан с архетипом тени, в котором характеристика врага представляет собой проекцию собственных страхов и комплексов.

Говоря о «миротворчестве» в политической деятельности Я. Арафата, мы сталкиваемся с парадоксом, причем таким, который до некоторой степени затрудняет его анализ. С одной стороны, миротворчество означало очевидную трансформацию стратегии Ясира Арафата (ее изменение), но не радикальную, которая позволяла приобрести ему междуна- родный авторитет, выступая в роли (маске) миротворца, поскольку другой альтернативной цели (если не рассматривать терроризм), кроме как позиционировать себя в данном статусе, у него не было. Столь резкая перемена в стратегии подчеркивала непрочность палестино-израильских отношений. С другой стороны, «миротворчество» Я. Арафата не исключало отказа от уничтожения Израиля путем продолжения террористической войны, которая выступала скорее правилом, чем исключением, рассматриваемая им как независимая политика от других арабских стран. Необходимо сказать, что идея уничтожения Израиля по-прежнему сохраняет большую власть над воображением палестинских арабов и в высшей степени отвечает их притязаниям. Смена статуса Арафатом не позволяет говорить об изменении его взглядов, убеждений и, тем более, о его стремлении к миру в палестино-израильских отношениях. Не будем забывать о том, что Арафат не пришел в политику как миротворец.

Я. Арафат, чья политическая карьера покрывает огромный отрезок истории палестино-израильского конфликта, последователен в попытках канализировать всеобщую готовность палестинских арабов к открытому насилию (в частности, терроризму), фокусируя ее на Израиле. По мнению Ж. Бодрийяра, «терроризм ничего не изобретает и ничего открывает. Он просто доводит все до крайности, до пароксизма. Он обостряет определенный порядок вещей, определенную логику насилия и неуверенности» [2]. И, наоборот, только отсутствие насилия не работает. Склонны предположить, что идеология терроризма появляется там и тогда, когда становится очевидным отсутствие возможности целого этноса, несмотря на свою разнородность, конструировать свое будущее в соответствии с определенными целями, задачами и интересами. В этом случае терроризм становится уже радикальным средством реализации интересов и достижения целей.

В отсутствии ощутимых результатов в урегулировании палестино-израильского конфликта влечение палестинцев к терроризму и их право на войну против Израиля остается неизменным. Евгений Сатановский говорит: «Наработанная на протяжении десятилетий система «борьбы за их права» (как 
шутят они сами, до «последнего палестинца») превратилась в самоподдерживающуюся международную политическую силу, заинтересованную в увековечивании их противостояния с Израилем и сохранении бюджетов, выделяемых им спонсорами» [12]. Между тем отсутствие результатов становится источником усиления реваншистских настроений палестинских арабов, в сознании которых закрепился комплекс «непреодоленного прошлого» .

Думается, что не будет преувеличением сказать, что чрезмерное отождествление Ясира Арафата с миротворчеством делает проблематичным существование самой идеи миротворчества, которая нужна была ему для обоснования палестинской государственности и изменения статус-кво палестинских арабов. В данном случае лидер ООП Я. Арафат выступает и позиционирует себя именно как миротворец с ускользающей сущностью, так как его миротворчество воплощало в себе иллюзию общих интересов палестинского народа и опиралось на три фактора: во-первых, необходимость односторонних уступок со стороны иноверцев («Зимми»); во-вторых, систему договоренностей, основанную на уступках, которая в свою очередь основана на доверии; в-третьих, систему временных перемирий и долговременного давления с помощью дипломатии, террора и насилия. Очевидно, что миротворчество Арафата имеет множество смыслов: это, во-первых, процесс строительства будущего Палестины на основе признания Израиля частично легитимным государством на определенный период времени, который неизбежно завершится истощением его сил и превращением израильтян в «Зимми», которым предоставляется возможность существовать под властью исламского правления; во-вторых, под видом миротворчества резервировалось понятие «временного перемирия»; в-третьих, миротворчество в скрытой форме предполагало неизбежное фронтирное изменение жизненного пространства между Палестиной и Израилем.

Нельзя сказать, что миротворчество Арафата преследовало цель урегулировать палестино-израильский конфликт. С этой точки зрения его миротворческая политика несла в себе заряд опасности, так как она не предполагала мирного сосуществования с Израилем, а значит — приводила к обратному результату.

Одновременно к миротворчеству Арафата надо подходить как к недостроенной конструкции идейно-информационного инструмента политики, которое ситуативно от начала и до конца и представляет собой совокупность тактических ходов, а не выверенной внешнеполитической стратегии, поэтому миротворчество выступает как призрачный кокон, в который упакован палестинский религиозно-националистический терроризм.

Безусловно, Я. Арафат никакой не миротворец. Но не в этом все дело. Он очевидно, доволен, что его назвали миротворцем. Дело не в том, кто ты есть, главное, знак подать. Итак, резкий поворот и аберрация взглядов Я. Арафата в сторону стратегии миротворчества были обусловлены рядом причин:

1) террористические действия не обеспечили достижения поставленных целей («сбросить евреев в море») и одновременно оказались неэффективными как способ борьбы за формирование палестинского государства;

2) негативная реакция мирового сообщества на террористическую деятельность Арафата, одновременно отягощенную недовольством ряда арабских стран, вызванным ухудшением их положения в переговорном процессе с европейскими странами;

3) недовольство палестинского населения отсутствием приемлемого урегулирования палестино-израильского конфликта, чье общественное мнение выступало фактором давления на политические элиты.

Монополизация арабами Палестины пространства памяти о Катастрофе 1948 года, а также поражение в войне 1973 года стали решающим стимулом, который давал Арафату возможность выступить с идеей миротворчества. Кроме того, Арафат не мог игнорировать события, которые происходили с конца 60-х годов. «На ближнем Востоке все громче заявляли о своих требованиях палестинцы. Дело уже не ограничивалось проблемой беженцев и защитой их прав. Палестинское движение превращалось в военно-политический фактор», - пишет А. Васильев [4].

По инерции для миротворчества была выбрана формула - не согласие и взаимодействие, а «временное перемирие», которое максимально отвечало интересам палестин- 
ских арабов, чья историко-культурная идентичность находится в процессе своего становления. В итоге Я. Арафат как законный представитель палестинского народа начинает активно пропагандировать себя в роли миротворца (даже тогда, когда им не являлся), защитника палестинских арабов. Напомним, что глава Иордании «король Хусейн роль защитника и представителя интересов палестинцев прочил себе» [13].

Миротворчество Ясира Арафата можно разделить на три этапа. Первый - выступление на трибуне ООН в 1974 г., в ходе которого он сумел сделать свою точку зрения публичной, в итоге палестинская проблема оказалась в центре мировой политики. Именно она разделила его на сторонников и противников палестинской государственности. Второй — переговорный процесс «Осло» или «Норвежские соглашения», итоги которого «оставили в стороне множество нерешенных деталей и вызвали шквал недовольства с обеих сторон» [10]. И, наконец, третий - дипломатический диалог с премьер-министром Израиля Эхудом Бараком, в ходе которого стало ясно, что очередная попытка урегулирования палестино-израильского конфликта превратилась в свою противоположность в энтропию двусторонних отношений. Переговорный процесс показал, что ничего не менять в палестино-израильских отношениях еще опаснее, чем рисковать, осуществляя попытки урегулирования конфликта, проблема которого заключается в том, что нет единого понимания в его осуществлении. В то же время результаты переговоров создали иллюзию быстрого урегулирования, но никогда, как покажут дальнейшие события, не приводили к желаемому результату. Что касается самого Арафата, то с завершением переговорного процесса, не достигшего точки необратимости, его миротворческий статус рухнул, он снова будет наносить по Израилю террористические удары, которые будут нацелены на то, чтобы остановить процесс нормализации палестино-израильских отношений, несмотря на односторонние усилия Израиля.

Позиция Я. Арафата, выражающего интересы палестинского народа, оставалась абсолютно предсказуемой, а главное - неизменной. Это были разные этапы, в ходе которых решения проблемы палестино-израиль- ского конфликта не было найдено, а результаты переговорного процесса не транслировались в дальнейшие шаги и действия по его урегулированию, так и не выйдя за пределы целеполагания. Тем не менее, произошло укрепление образа и чувства идентичности палестинского народа, несмотря на то, что переговоры увязли в проблемах урегулирования конфликта.

Итак, «новая» тактика лидера Организации Освобождения Палестины (ООП) Я. Арафата в ноябре 1974 г. - трибуна ООН, с которой он обратился уже не к враждебно настроенному мировому сообществу, а к такому, которое было заранее расположено в пользу арабов Палестины. Как следствие, «большинство делегатов Генеральной ассамблеи открыто выражает Арафату свою симпатию. Представители почти 140 стран встают, чтобы продемонстрировать свое уважение Арафату, а в его лице - ООП и палестинскому народу», - указывает Г. Концельман [9]. Тем более что «в те годы, как и сейчас Организация объединенных наций признавала право народов на национально-освободительную борьбу...» [7]. Безусловно, тактика Арафата носила спектакулярный характер (назовем ее «театр для других»), в рамках которой предстояло не только привлечь внимание мировой общественности (немусульманской прежде всего) к палестинскому вопросу, значимость которого в современном мире сильно преувеличена (по причине конфликтного потенциала), но и фактически сделать Организацию Объединенных Наций своим надежным союзником, проводником позиции палестинских арабов. Александр Брасс справедливо отмечает: «С каждым годом Арафат и другие лидеры ФАТХ все больше убеждались в том, что Палестину можно освободить без участия такого ненадежного союзника, как арабские страны» [3].

Я. Арафату нужна была реакция мировой общественности, чтобы его цель стала их целью, и он, как покажут дальнейшие события, ее достиг, значит, его методы борьбы и ведения компании против Израиля были эффективными, ибо они побудили мировое сообщество принять позицию арабов Палестины, после чего «на международной политической арене еврейскому государству суждено было играть роль изгоя, отчего оно стало уязви- 
мее, чем когда-либо прежде», - справедливо указывает Даниэль Гордис [6]. Отсутствие взвешенной позиции в ООН по отношению к Израилю привело к тому, что его международный имидж значительно пострадал. Нет сомнений в том, что последствия такой позиции международного сообщества оказались, скорее всего, отрицательными, ибо она отражала не только интересы палестинской стороны, а также динамику понимания сути конфликта.

Постфактум попытаемся придать этому событию - выступлению Арафата«миротворца», в котором он говорит о необходимости создать на территории Палестины новое объединенное арабо-еврейское государство, какой-либо смысл. Смысл же заключался в том, что за пределы обвинительной риторики выступление, в котором сионистское движение было поставлено на одну ступень с расизмом, апартеидом и нацизмом (как нацизм виновен в Холокосте, так и зеркально сионизм виновен в Нагбе), не выходило, то есть оно носило провокационный характер, и, как следствие, не приводило к появлению новых практических идей в урегулировании палестино-израильского конфликта.

Намеренно или нет, но выступление Я. Арафата привело именно к такому результату — возникновению опасности имитации урегулирования конфликта. Тем не менее, сам факт выступления Арафата важен и показателен, ибо, судя по реакции на его выступление, потенциал поддержки идеи палестинской государственности оказался чрезвычайно высок. Безусловно, свою роль сыграли дипломатические атаки палестинцев на Израиль, как и события, связанные с давлением арабских государств на европейские страны, напуганные введением эмбарго нефти после войны 1973 года.

Данное обстоятельство свидетельствует о том, что многие проблемы конфликта вызваны невозможностью его урегулирования на основе ситуативных решений сторон под давлением тех или иных обстоятельств.

Эффектное выступление лидера палестинских арабов, последовавшее 13 ноября 1974 года на торжественном заседании ООН, на котором он появился без традиционной бороды (признака религиозного благочестия, символа борца с врагом, символа, который понятен и исторически принят палестинским миром, так как лицо - это дополнительная оливковая ветвь - я не моджахед, я миротворец) стало событием, которое подвержено множеству интерпретаций, но не сводимо к окончательной. Отметим, что интерпретация исторического события неизбежно зависит от содержания нарративов и мифов, которые создаются и формируются участниками конфликта с его неструктурированным набором символов и значений.

О том, что представляет собой Арафат«миротворец» в 1974 году, ярче всего рассказывает его продолжительное выступление, которое он посвятил не миру с Израилем, как, казалось бы, должно быть, а «еврейскому вторжению в Палестину» [6]. На историческом заседании он выступил на арабском языке перед делегатами Генеральной Ассамблеи ООН, которое можно рассматривать как выступление-предписание, как выступлениедействие, выступление-призыв, обращенное к мировому сообществу, которое не утверждалось прямо, но подспудно внушалось. На Генеральной Ассамблее ООН «Я. Арафат, искусно сыгравший роль миротворца и одновременно не сложившего оружия борца, в своей проникновенной речи с трибуны ООН призвал международное сообщество помочь палестинскому народу в его усилиях по достижению права на самоопределение и создание национального независимого суверенитета на своей собственной земле» [11].

Ограничимся только одной цитатой из выступления Арафата, вызвавшего одобрение присутствующих на заседании ООН. В ней указывалось, в частности: «Как председатель ООП и как лидер палестинской революции я заявляю перед настоящим собранием, что завтрашнюю Палестину мы планируем и для всех евреев, которые сегодня живут в Палестине и хотят жить совместно с нами на палестинской земле, свободной от дискриминации». Особенность его обращения заключается в том, что «Арафат не создает пропасти. Он подчеркивает готовность к примирению и к диалогу, предлагает евреям партнерские отношения», - отмечает Г. Концельман [9].

Несмотря на то, что точка зрения Арафата была далеко не беспристрастной, вышеизложенный взгляд убедителен, но в нем 
смущает внеисторический подход лидера палестинского народа на географию, территорию, народы пространства палестинской ойкумены, преувеличенная роль сионизма в бедственном положении палестинских арабов, в общественном сознании которых сионизм ассоциируется с вытеснением палестинских арабов с родной земли, с использованием для этого всех методов (намек на этнические чистки Израиля). Склонны предположить, что выступление Арафата можно рассматривать как версию урегулирования конфликта не на основе того, что есть, а на основе того, что должно быть, которую он возвел в ранг абсолютной истины, извлеченную из долговременного опыта палестино-израильских противоречий и основанную на нем. Безусловно, она отражала соблазн арабов Палестины, привязанных к идее палестинской государственности, глубоко укорененной в идеологическом и религиозно-националистическом духе ментальности «палестинцев».

Манипулятивный язык Я. Арафата, знавшего силу слова, скрывал глубокие процессы, посредством которых лидер палестинских арабов пытался повлиять на Запад, оставляя его в состоянии глубокой раздвоенности между реакцией на события в Палестине, беспрецедентным одобрением и симпатиями к палестинской революции и ритуальным осуждением действий Израиля. Отметим, что речь Я. Арафата, целью которой было воздействие на мировое общественное мнение, вовлекала его в иллюзорное пространство, делала его частью воображаемого пространства. Как известно, в иллюзорном состоянии сознание людей наиболее управляемо, так как оно напоминает сознание зрителя, ибо воображаемое внушает, изменяя реальное, ему подчиняются вопреки всяким формальностям. Вместе с тем атака Арафата на Израиль посредством ООН приводила к делегитимизации еврейского государства, как следствие - подрыву основ его безопасности.

По сути, Арафат продвигал принципиально новый способ реагирования Запада на оценку палестинского национально-освободительного движения (отметим, что палестинский народ никогда не был субъектом данного движения), подталкивая западные элиты рассматривать его как символ справедливой борьбы за национальное освобождение. Образ палестино-израильского конфликта в риторике Арафата первичен по отношению к самому конфликту как к факту. Однако, здесь Арафат допускает, что фундаментальный факт самого конфликта может быть более или менее трансформирован и искажен в его образе, в восприятии, работая на пропагандистские цели ООП, которая получит признание со стороны Генеральной Ассамблеи $\mathrm{OOH}$, несмотря на характер ее деятельности. И снова обратимся к высказыванию А. Брасса, который подчеркнул: «Нет сомнения в том, что 13 ноября 1974 года Организация Объединенных Наций, хочется верить, неосознанно, дала «зеленый свет» международному терроризму в лице ООП» [3].

Ясир Арафат уловил важную тенденцию - эпоха телевидения и интернета превращает слова в желаемые образы, а не наоборот, посредством которых конструировалось сознание и поведение людей, которым передавалась травматическая «откровенность» палестинского народа, а образ палестино-израильского конфликта непрерывно смещался в сторону эмоций. В итоге Арафат выступил в роли продавца его желаемого образа и творца эмоциональной вселенной европейского слушателя, в сознании которого миражи приобретали устойчивый характер. Отметим, что если европейский слушатель не хотел приближаться к миражу, то, напротив, ООН движется по логике Я. Арафата. Как следствие, 22 ноября 1974 года Генеральная Ассамблея ООН приняла резолюции №3236 и №3237. В первой из них говорилось о том, что «палестинский народ имеет право на самоопределение в соответствии с Уставом Организации Объединенных Наций», что было несомненной победой палестинской дипломатии, несмотря на то, что понятие палестинского государства в данной резолюции не постулировалось. Резолюция №3237 приглашала Организацию освобождения Палестины участвовать в сессиях и работе Генеральной ассамблеи качестве наблюдателя.

Проблема заключается в том, что Я. Арафат оттягивает время урегулирования конфликта до бесконечности, а принятие решения по его преодолению до неразрешимости, что, 
несомненно, разрушало благую цель арабов Палестины - формирование государства. Поэтому Арафат как миротворец малоэффективен, что объяснялось как чрезвычайной пестротой палестинского общества (не мог объединить интересы всех), так и неоднородностью поддержки, как со стороны христианского, так и исламского миров.

Подводя итоги, можно сделать ряд выводов. Во-первых, Ясир Арафат, во всяком случае, никаким миротворцем не был и не мог им стать, что может интерпретироваться как присвоение мнимого образа с нереализуемым содержанием. Он вообще не вписывался в рамки миротворческой деятельности - это была часть его рациональной внешнеполитической стратегии в ограниченной временной перспективе. Если признать в Арафате миротворца, то будет логично предположить возможность практической реализации мира в арабо-израильском конфликте «по Арафату». Во-вторых, совершенно очевидно, что не столько конфликт сам по себе, сколько манипуляция международным общественным мнением (непросвещенными слушателями) в пользу палестинских арабов, шантаж образом непостижимого страдания и, как следствие, возможным негативным сценарием, содействовали искажению реальности и транспарентности палестино-израильских отношений, их презентации в жалостливой форме палестинских страданий. В-третьих, нельзя не учитывать того обстоятельства, что палестино-израильский конфликт для $\mathrm{OOH}$ не стал источником достоверного отображения реальности и постижения истинных движителей мирового процесса на арабском востоке.

Поступила в редакичию

\section{Литература}

1. Армстронг К. Иерусалим: Один город, три религии. - М.: Альпина нон-фикшн, 2017. - $566 \mathrm{c.}$

2. Бодрийяр Ж. Дух терроризма. Войны в Заливе не было. - М.: РИПОЛ классик, 2017. - $226 \mathrm{c}$.

3. Брасс А. Палестинские истоки. - М.: ООО ИД «Русь» — «Олимп»; ОЛМА-ПРЕСС Образование, 2004. - 347 с.

4. Васильев А. М. От Ленина до Путина. Россия на Ближнем и Среднем Востоке. М.: Центрполиграф, 2018. - 670 с.

5. Гейзель 3. Политические структуры Государства Израиль. - М.: Иерусалим: Мосты культуры, Гешарим, 2013. - 664 с.

6. Гордис Д. Израиль: история государства. - М.: Мосты культуры, 2018. - 488 с.

7. Дзасохов А. С. Человек и политика. М.: ИИК «Российская газета», 2009. - 398 с.

8. Дершовиц А. Слово в защиту Израиля. - М.: Текст, Книжники, 2011. - 476 с.

9. Концельман Г. Ясир Арафат. Серия «След в истории». - Ростов-на-Дону: «Феникс», 1997. — 480 с.

10. Монтефиоре С. С. Иерусалим. Биография. - М.: Издательство ACT: CORPUS, 2018. - $720 \mathrm{c}$.

11. Носенко Т. В., Семенченко Н.А. Напрасная вражда. Очерки советско-израильских отношений 1948-1991 гг. - М.: ИВ PAH, 2015. - $260 \mathrm{c}$.

12. Сатановский Е. Ближний Восток: политическая мифология и реальное положение дел // Эксперт. - №22. - 2018. - С. 44-49.

13. Штереншис М. История государства Израиль 1896. - 2005. - Герцлия: ISRADON, 2005. - $720 \mathrm{c}$. 


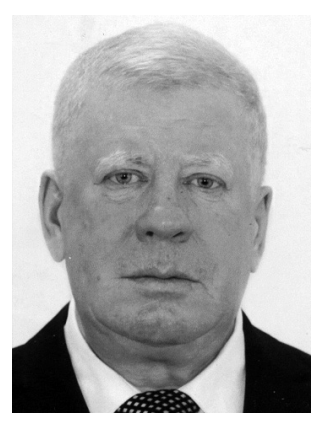

Прядеин Владимир Станиславович - доктор исторических наук, профессор, профессор кафедры истории России филиала Уральского федерального университета в г. Верхняя Салда.

Pryadein Vladimir Stanislavovich - doctor of historical Sciences, Professor, Professor of the Department of Russian history of the branch of the Ural Federal University in Verkhnyaya Salda.

624760 , г. Верхняя Салда, ул. Рабочей молодежи, 1

1 Rabochey molodiezhy st., 624760, Verkhnyaya Salda, Russia

Тел.: +7 (34345) 5-04-69; e-mail: olkenn@yandex.ru

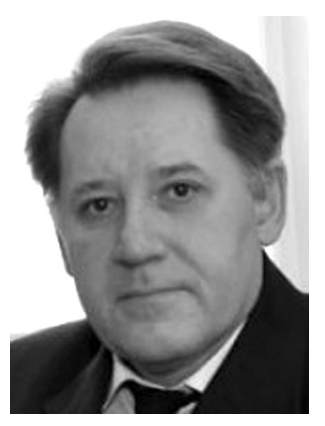

Абрамов Сергей Михайлович - кандидат педагогических наук, доцент кафедры управления персоналом Уральского государственного горного университета.

Abramov Sergey Mikhailovich - candidate of pedagogical Sciences, associate Professor of the Department of personnel management of the Ural state mining University.

620144, г. Екатеринбург, пер. Университетский, 7

7 Universitetsky $\ln ., 620144$, Yekaterinburg, Russia

Тел.: +7 (922) 112-83-62; e-mail: AbramowwwSM@mail.ru

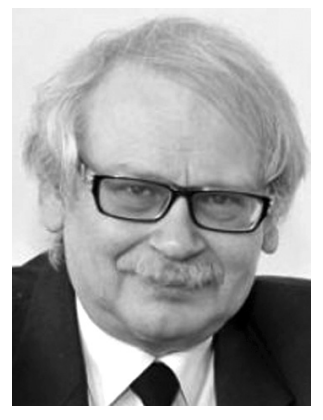

Акулов Сергей Александрович - старший преподаватель кафедры управления персоналом Уральского государственного горного университета.

Akulov Sergey Alexandrovich - senior lecturer of the Department of personnel management of the Ural state mining University.

620144, г. Екатеринбург, пер. Университетский, 7

7 Universitetsky ln., 620144, Yekaterinburg, Russia

Тел.: +7 (950) 637-17-90; e-mail: ief.up@m.ursmu.ru 


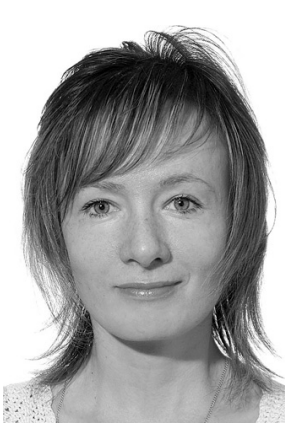

Пашкевич Наталья Александровна - кандидат исторических наук, доцент кафедры общенаучных дисциплин Уральского государственного университета путей сообщения (филиала) в г. Нижний Тагил.

Pashkevich Natalia Aleksandrovna - candidate of historical Sciences, associate Professor of the Department of General scientific disciplines of the branch in Nizhniy Tagil of the Ural state University of Railway Transport.

622013, г. Нижний Тагил, ул. Садовая, 97, кв. 278

97 Sadovaya st., app. 278, 622013, Nizhny Tagil, Russia

Тел.: +7 (952) 140-55-30; e-mail: alvp28032008@yandex.ru 